\title{
Városlakó nomádok 2.0
}

\section{A mongóliai terepmunka új perspektívái a 21. században"}

Ha ma valaki leszáll a Dzsingisz Kán Nemzetközi Repülőtéren, és beutazik Ulánbátorba, akkor egy olyan nyüzsgő, autókkal, modern épületekkel telezsúfolt várost talál, amely kevés dologban különbözik Ázsia vagy a világ más nagyvárosaitól. E forgatagban lépten-nyomon találhat arra utaló jeleket, hogy egykori „,nomádok” között jár, de ahhoz, hogy a végtelen pusztákon legelésző állatokat, jurtákban élő nomád pásztorokat láthasson, még hosszú utat kell megtennie. Nehéz megtalálnia azt a Mongóliát, amely az emberek fejében él. Ezt a tényt az arra járó utazóknak is el kell fogadniuk, de ez az új környezet a mongol kultúrával foglalkozó kutatók számára is új helyzetet és egyúttal új lehetőségeket is teremt, hiszen a mai Mongólia megértéséhez és megismeréséhez új utak, más témafelvetések vagy új kutatási szemlélet vihetnek közelebb.

Mongóliában a 20. század utolsó évtizedét bevezető politikai változások - illetve azok következményei - jórészt egybeestek azokkal a mongol életre (is) rendkívül jelentős hatást gyakorló, a nyugati kultúrából kiinduló és az egész világot érintő egységesítő gazdasági, társadalmi és kulturális folyamattal, melyet ma globalizációként ismerünk. ${ }^{1}$ E látványos átalakulásnak és fokozott hatásának az oka az volt, hogy az 1990-es évek előtt az országban - de szélesebb perspektívából tekintve az egész térségben - jellemző politikai folyamatok sok tekintetben konzerválták (vagy, ha kissé megengedőbben fogalmazunk, kevésbé változtatták meg) azt a hagyományos életformát, kultúrát, melyet legelőváltó nomád gazdálkodásként, illetve nomád kultúraként ismerünk, és amelyre sokan asszociálnak mind a mai napig, ha Mongólia szóba kerül.

Jelen kutatást az OTKA 109043 számú kutatási programja támogatta.

1 Cséfalvay 2004. 
Az elmúlt alig több mint negyed évszázadban, de különösen az utóbbi tizenöt évben bekövetkezett társadalmi, kulturális átalakulás olyan jelentős mértékü volt, hogy nemcsak a mongolok mindennapi életét alakítja, de hatással kell lennie a mongol kultúrával foglalkozók munkájára is. Ez a mai környezet új szemléletet, kutatási módszereket igényel a tudományos munkában, s miközben kétségtelen tény, hogy a hagyományos nomád kultúra megmaradt elemeinek feltárása, dokumentálása sürgetőbb, mint valaha, a Mongóliában zajló változások nyomon követése legalább ilyen fontos feladat. Az elmúlt évtizedben e sorok írója is egyre több figyelmet fordított ezekre a folyamatokra, az MTA által támogatott kutatási projektek fókuszában is ez a kérdés áll. ${ }^{2}$ Első tapasztalataimat néhány cikkben is összegeztem. ${ }^{3}$ Mivel a folyamat a szemünk előtt zajlik, jelenleg inkább csak dokumentálhatjuk a folyamatokat, kísérletet téve ezek megértésére.

Tény, hogy az ország lakosságának jelentős része mind a mai napig azt a nagyállattartó nomád életmódot folytatja, mely évezredek óta jellemző volt a térségben, s napjainkig alapjait tekintve nem, vagy csak igen kis mértékben változott. Ugyanakkor egyértelmü, hogy a mongol pásztorok ma már kisebbségben vannak, az életforma láthatóan visszaszorulóban van még Mongóliában is, pedig az országot hagyományosan a belső-ázsiai nomád kultúra utolsó bástyájának tekintjük. Ez az életmód egyre fokozódó mértékben szorult vissza elsősorban annak a gazdasági változásnak köszönhetően, melynek alapjait az 1990 -es politikai rendszerváltás, ${ }^{4}$ illetve az azt követő gazdasági átalakulás, információs forradalom és a globalizáció egyéb hatásai teremtették meg. Mongóliában beköszöntött a piacgazdaság korszaka (halha jax jēlīn üye), ami első körben igen komoly krízist okozott - erröl később röviden még szólni fogunk -, majd az ebből való fokozatos kiemelkedés során alapvetően változott meg a mongol gazdaság struktúrája, s ez a folyamat utóbb igen jelentős társadalmi átalakulást generált.

Ezeket a változásokat a jelen munka szerzője jórészt testközelből figyelhette, hiszen immár negyedszázada tagja az 1991-ben indult Magyar-mongol

2 Az MTA a Mongol Tudományos Akadémiával közös - 2014-ben megújított - magyar-mongol akadémiai együttmüködés keretében a 2015-2017-es ciklusban már önálló bilaterális projekttel is segítette a mongóliai kutatásokat. Ilyen a szerző témavezetésével folyó Hagyomány és modernizáció. Folklór és etnológiai kutatások Mongóliában címü bilaterális kutatási program.

3 Szilágyi 2010b, 2015, 2016.

4 Szilágyi 2015. 
népi müveltség- és nyelvjáráskutató expedíciónak, mely 25 éve végez gyüjtőmunkát a mongol vidéken. E munka során a résztvevők nem hagyományos értelemben vett (állomásozó) antropológiai terepmunkát végeznek, ${ }^{5}$ de ahhoz szorosan köthető terepmunkamódszerekkel dokumentálták, dokumentálják a mongol nomádok szellemi és anyagi kultúráját.

A folyamatosan átalakuló környezet, a változó terep azonban az évek során hatással volt a programra, új irányba is terelte az évről évre visszatérő kutató figyelmét. Jelen cikk az eddig kialakult tapasztalatok alapján arra vállalkozik, hogy röviden bemutassa, a Mongóliába utazó kutató mit tapasztalhat ezekből a változásokból, hogyan változott, változik meg a „terep”, és ez hogyan hat vissza a kutatásra, akár magára a terepmunkára is. ${ }^{6}$

A cél elsősorban az, hogy az eddigi tapasztalatok alapján általános képet adjunk arról, hogy a mongol kulturális hagyomány, a mongol identitás, a népvallás vizsgálata során milyen új kérdések vetődtek fel az expedíció indítása óta. Ehhez nagyon röviden bemutatjuk a közös magyar-mongol kutatómunkát, s a teljesség igénye nélkül tárgyalunk néhány olyan kérdést a „két mongol társadalom”, a kulturális rivalizálás, a népi vallásosság tekintetében -, melyek a munka folytatásának területei lehetnek.

\title{
A „hagyományos terep"
}

A közös magyar-mongol terepkutatás azokban az években indult, amikor a rendszerváltással a huszadik század utolsó évtizedébe lépő Mongólia történetének egyik jelentős válságával volt kénytelen szembenézni. Az 19901992-ben lezajlott politikai átalakulás egyik sarkalatos kérdése volt a piacgazdaságra való áttérés. Ezzel párhuzamosan azonban a korább struktúrák lebontásának köszönhetően Mongólia gazdasági értelemben válságos helyzetbe került. ${ }^{7}$ A KGST összeomlásának és az orosz-mongol kapcsolatok mélypontra kerülésének köszönhetően Mongólia elvesztette hagyományos exportpiacainak jelentős részét, az import minimálisra csökkent, a városokban áru- és élelmiszerhiány alakult ki, a kilencvenes évek elején az alapvető élelmiszereket jegyre árusították.

\author{
Bakó 2004. \\ Boross 2004. \\ Szilágyi 2010a: 123-126.
}


A rendszerváltás során az 1960-as, 1970-es és 1980-as években lezajlott, elsősorban a kollektivizálás és iparosítás alapján folytatott - és csak részleges eredményeket hozó - modernizáció irányai mentén kialakított nagyobb települések a felpezsdülő politikai élet és az ebből fakadó változások központjai voltak. Ugyanakkor a válságban drasztikusan romló gazdasági helyzet, a csökkenő munkalehetőségek következtében e városok meglehetösen szükös körülményeket biztosítottak a mindennapi megélhetésre. A kilencvenes évek elején az állam a szociális juttatásokat jelentős mértékben csökkentette, a reálbér zuhant, így a gazdasági krízisnek köszönhetően csaknem a lakosság egyharmada volt kénytelen a létminimum alatti jövedelemből élni. ${ }^{8}$ Ennek a ténynek is köszönhetően a rendszerváltást követő években kisebb belső migráció indult a városokból a vidék felé.

Ezekben az években kialakult a nomád életmód egyfajta reneszánsza, amit gyakran a kényszerüség is táplált. 1991-ben országos program indult az állami vagyon privatizálására, amit állami kötvények (halha tasalbar) kibocsátásával kívántak megvalósítani. A vidéki területeken ez a program elsösorban a korábban létrehozott állami gazdaságok (halha sangiin aj axui) és szövetkezetek (halha negdel) felszámolását jelentette.

Sokan tértek vissza a hagyományos nomád állattartáshoz, mert ez az új keretek között is megélhetést biztosíthatott a családjuknak. Jelen sorok írója 1992-ben Dzavhan (halha Jawxan) megyében találkozott olyan általános iskolai tanárral, aki az előző évben hagyott fel oktatói munkájával és költözött vidékre a családjával. Az 1992. január 13-án elfogadott új alkotmány ismét visszaadta a szabad költözés jogát a mongol állampolgároknak, így immár jogi akadálya sem volt annak, ha valaki az egyre szegényedő városi környezetből vidékre kívánt költözni. 1990 és 1993 között a mongol pásztorok lélekszáma 136 százalékkal nőtt. ${ }^{10}$

A vidékre költözők alapvetően a biztosabb megélhetésért választották a nomád életmódot. A kiköltözők kisebb részét vezérelte az urbanizációtól való elfordulás, illetve a hagyományos nomád értékek és életmód tudatos választása. 1935-1985 között ötven év alatt Ulánbátor lélekszáma csaknem ötvenszeresére emelkedett, ${ }^{11}$ és az 1970-80-as években kialakult két másik jelentős ipari központtal (Erdenet és Darxan) együtt immár a mongol lakos-

\footnotetext{
Sneath 2006: 150, Robinson 1995: 4.

Sneath 2006: 149.

Shi 2011.

11 Sneath 2006: 147.
} 
ság több mint 50 százaléka urbanizált környezetben élt. ${ }^{12}$ Ennek ellenére a főváros teljes mongol lakossághoz viszonyított lélekszáma, illetve gazdasági túlsúlya ebben a korszakban még nem volt olyan elsöprö, mint az utóbbi években. A 20. század utolsó évtizedének elején a mongolok jelentős része még nomadizált, a föváros lakossága alig haladta meg a $25 \%$-ot ${ }^{13}$ a teljes népességre vetítve. ${ }^{14}$

A vidékre költözés, a nomád életmódot választók számának növekedése azonban csak látszólag jelentette a hagyományos életmódhoz való teljes visszatérést. A társadalmi átrendeződés, a vidék felé irányuló belső migráció korántsem jelentette hosszú távon fenntartható egyensúly kialakulását. Miközben a nomád gazdálkodásból élők száma a hivatalos adatokban is szignifikánsan emelkedett - míg e létszám 1989-ben 135420 fö, a munkával rendelkezők kevesebb, mint 18 százaléka, addig 2001-ben már több mint 50\%, 407030 fö -, területi eloszlásuk nem volt ideálisnak mondható. A legtöbben csak részben adták fel a városi életmód nyújtotta kényelmet. ${ }^{15}$

Sokan a járásközpontok környezetében legeltették állataikat, az őszi, téli szállásokon sokszor több család közösen hajtotta legelöre jószágait. Ez a gyakorlat korábban is megfigyelhető volt, nem idegen a nomád hagyományoktól, de ilyen mértékben sosem volt jellemző. Sokan önerejükből egyszerüen képtelenek megoldani az évszakonkénti költözést, ezért gyakran az általuk legjobbnak ítélt legelőn töltik az egész évet. Ez alapvető változás a nomadizmus történetében, hasonlóra kevés példa akadt a korábbi évszázadokban.

Az állatállomány ilyen nagy tömegben, viszonylag szük területen történő tartása óhatatlanul túllegeltetést eredményez, ami nemcsak a legelők drasztikus romlásával, de ennek következtében az állomány kondíciójának rosszabbodásával, a mostoha természeti körülményekkel szembeni ellenálló képesség gyengülésével járhat. Az ezredfordulón megfigyelhető jelentős csökkenés ezekre az okokra is visszavezethető. Az 1999-ben 33,6 millió állatot számláló állomány óriási veszteségeinek köszönhetően a teljes szám alig három év alatt csaknem tízmillióval csökkent, 2002-ban 23,9 milliós

12 Algaa 2007.

13 Gilberg- Svantesson 1996: 21.

14 A teljes népesség 2184145 fő volt, míg a főváros lélekszáma 545760 lakost számlált. http://www.un.org/esa/population/publications/wpp2006/WPP2006_Highlights_rev.pdf (utolsó megtekintés: 2017. október 5.).

15 Humphrey - Sneath 1995: 11-13. 
adatot rögzítettek. ${ }^{16} \mathrm{Az}$ elmúlt másfél évtizedben azonban az állatállomány drámai mértékben növekedett, s az összlétszám 2010-re immár a 45 milliót is megközelítette. ${ }^{17}$

Ha pusztán a nomád életmód terjedésének szempontjából vizsgáljuk a kérdést, megállapítható, hogy a magyar-mongol expedíció a legjobbkor kezdhette meg munkáját. Az 1991-es első kutatóút idején és a következő években is Mongóliában olyan terepen mozoghatott, amely alapvető jellemzőiben nem tért el jelentősen a fél, de akár az egy évszázaddal korábbi állapotoktól sem. A lakosság jelentős része évszakonkénti legelőváltó, nagyállattartó nomád gazdálkodást folytatott, a hagyományos nomád anyagi müveltség legtöbb eleme könnyen megfigyelhető volt, a korábbi évtizedekben bevezetett, felülröl irányított modernizáció az eszközhasználatban, az állatokkal kapcsolatos tevékenységek tekintetében csak ritkán volt tetten érhető.

Ugyanakkor elmondható, hogy a kutatási program indulásakor a kutatók által megfigyelt témakörök, így a folklór, a szellemi müveltség, a vallás vagy a nyelvjárások vizsgálata sem ütközött jelentősebb akadályokba, mint esetleg a rendszerváltás előtt. A résztvevő kutatók a lehetőségeik adta kereteken belül éves rendszerességgel próbáltak visszatérni a terepre, $\mathrm{s}$ bár nem végeztek állomásozó terepmunkát, egy-egy adatközlőhöz akár több alkalommal is visszatértek. Ezek a gyakori találkozások, a jó mongol nyelvtudás, a hagyományos nomád életmód ismerete megkönnyítette a kutatást, amihez hozzájárult az is, hogy a magyar kutatók ebben a korszakban már szabadon mozoghattak a terepen, aminek általában csak kisebb adminisztrációs akadályai voltak - a szocialista rendszerben kialakult korlátozó intézkedések lebontása, a helyi és fővárosi rendőrség, illetve adminisztrációs szervek hozzáállásának megváltozása éveket vett igénybe. ${ }^{18}$

Az adott terepre, adott családhoz (adatközlőhöz) való visszatérést megkönnyítette, hogy ebben az időszakban nem volt jelentős a belső migráció, egy-egy nomád család szállásterülete évről évre viszonylag könnyen megtalálható volt azon a pár tíz négyzetkilométeres területen, amelyhez hagyo-

\footnotetext{
Sneath 2006: 153.

Avar 2014: 11.

18 1998-ben a Hövszgöl (halha Xöwsgöl) megyei Cagán ür járásban (Cagān ür sum) még kötelező volt bemutatni a fövárosban szerzett határzóna-engedélyt, de mi volt ez ahhoz képest, hogy a rendszerváltás elött a főváros elhagyását is engedélyhez kötötték, az országba való belépésre jogosító mongol vízum csak adott városra, településre szólt?
} 
mányos nomád életmódja kötötte. Ezen belül az egyes évszakok, elsősorban a tavasz és nyár szállásai tekintetében lehetett eltérés, hiszen minden évben a legelők állapota, a csapadék és az elérhető ivóvíz határozza meg, hogy a család az általa hagyományosan használt területen hol állítja fel a jurtáját - de a terepmunkát ez nem nehezíti érdemben. Ráadásul a nomádok mindig jól tájékozottak szomszédjaikat illetően, így egy-egy adatközlő elérése ritkán jelent problémát.

Mint említettük, a kutatómunka egyik kiemelt területe a valláskutatás. Ennek vizsgálatához az 1990-es évek elejétől kezdődően a szabad vallásgyakorlat időszaka minden korábbinál jobb terepet biztosított. Általában egész Mongóliára jellemző volt a vallási újjászületés, mely a népi vallásosság, a sámánizmus, de a buddhizmus újjáéledésével is egyértelmű válasz volt a korábbi évek ideológiai alapon müködő vallásellenes politikájára. A buddhizmus újjáledésének számos jelével találkozhattunk a mongol peremvidékeken is, ami jó alkalmat teremtett a mongol népi vallásosság szinkretikus elemeinek vizsgálatára is. ${ }^{19}$

A vallási újjáéledés időszakában már nagyon korán megfogalmazódott a szocialista korszakban lerombolt, bezárt buddhista kolostorok újjáépítésének igénye is. A kilencvenes években itt-ott még éltek olyan lámák, akik kisgyermekként kapcsolatban álltak a jórészt az 1937-1938-ban tervszerüen lerombolt kolostorok valamelyikével, továbbá ebben az időszakban vidéken az egyes jurták házi oltárain nem ritkán találkoztunk olyan szakrális tárgyakkal - szobrokkal, a lerombolt kolostorokból származó díszekkel, néha könyvekkel -, melyeket a család nem ritkán évtizedekig rejtegetett, vagy nemrég ásott elő a kolostorrombolások idején kialakított rejtekhelyekről. Ezek a tárgyak egyrészt mindig jó alkalmat biztosítottak a helyi szakrális hagyománnyal kapcsolatos adatok gyüjtésére, másrészt gyakran legitimálták az adott közösség újjáépítést célzó tevékenységét.

Természetesen felvetődik a kérdés, hogy ezek a tárgyak mennyire tekinthetők a helyi közösség, az adott család tulajdonának, vagy esetleg múzeumban lenne a helyük. Hasonló kérdések merültek fel az általunk vizsgált mongol és tibeti kéziratokkal kapcsolatban is, melyekkel sajnos sok rossz tapasztalatot szereztünk. A kolostorrombolások idején ezeket volt a legkönnyebb megsemmisíteni, így óriási kulturális vagyon vált a pusztítás martalékává, ugyanakkor számos kézirat és nyomat vészelte át az évtizedeket elrejtve.

19 Birtalan 1996, 1998, 2004. 
Az írott szövegek a hozzá nem értők számára ritkán hordoztak olyan szakrális tartalmat, mint egy szobor vagy kegytárgy, így a rejtekhelyekről, gyakran hagyatékokból előkerülő szövegek egyrészt vidéken viszonylag könynyen hozzáférhetővé váltak, másrészt azonban nagyon hamar az ulánbátori feketepiacon láthattuk viszont őket. Az 1990-es évek végén ez utóbbi vált tendenciává, ezért volt különös jelentősége annak, hogy kutatásaink kezdettől fogva figyelmet szenteltek a terepen gyüjthető írott forrásoknak, illetve a 2000-es évek elejétól egy új program is indult a ritka írott anyag kutathatóvá tételére. ${ }^{20}$

\section{A magyar-mongol akadémiai együttmüködés}

A közös kutatóprogram ötletét még az 1990-es évek legelején fogalmazta meg Sárközi Alice, az MTA Altajisztikai Kutatócsoportjának tudományos főmunkatársa. A cél az volt, hogy az újkori magyar mongolisztikai kutatások kiinduló pontjának tekinthető, Kara György, Róna-Tas András és UrayKőhalmi Katalin részvételével 1957-ben megvalósult kutatóút alapján új, lehetőleg hosszú távú kutatási tevékenység indulhasson a Mongóliában élő nomádok között. ${ }^{21}$ Az ötlet az 1950-es évek végétől létező magyar-mongol akadémiai együttmúködésnek új lendületet adott, hiszen az új politikai környezet is elengedhetetlen feltétele volt, hogy terepen önálló néprajzi, régészeti vagy történeti kutatásokat lehessen végezni.

A rövid egyeztetések után 1990-ben jött létre az a megállapodás, amely megalapozta az expedíció tevékenységét. A programba magyar részről kezdetben az MTA Altajisztikai Kutatócsoportja és az ELTE Belsö-ázsiai Tanszéke, mongol részről a Mongol Tudományos Akadémia Nyelv- és Irodalomtudományi Intézete kapcsolódott be. ${ }^{22}$ Az előkészítés után 1991-ben indult

20 Ennek egy eleme a már említett UNESCO által támogatott sorozat (Treasures of Mongolian Culture and Tibeto-Mongolian Buddhism), illetve ide tartozik a 2017-ben a szerző vezetésével induló régi történeti dokumentumok digitalizálását végző program, melyet a British Library Endangered Archives programja támogat.

21 E kutatóútról írt népszerü összefoglalót Róna-Tas András Nomádok Nyomában. Etnográfus szemmel Belsö-Ázsiában címmel, mely kötet előszavának első szavaiban már ezt írja a nomadizmusról: „egy életforma tủnik el” (Róna-Tas 1961:5).

22 Az Altajisztikai Kutatócsoport 2006 végi sajnálatos megszünése után a program hazai irányítását a Belső-ázsiai Tanszék vette át, a finanszírozást pedig a különböző OTKA pályázatok (K 62501, K 100613, témavezető Birtalan Ágnes) keretében sikerült 
az az immár 25 éves kutatási program, melyet Magyar-mongol népi müveltség- és nyelvjáráskutató expedícióként ismerünk. ${ }^{23}$

A kutatás fő célja kezdetben az volt, hogy dokumentálja a Mongólia északi, középnyugati és nyugati megyéiben élő népcsoportok nyelvjárásait, nomád anyagi műveltségét, kulturális hagyományait, szakrális szokásait. Az expedíció vezetői Sárközi Alice és Birtalan Ágnes. A munkába már szinte a kezdetektől bekapcsolódtak az említett magyar oktatási mühely diákjai - ahogyan jelen cikk szerzője is -, így az expedíció gyakorlatilag az egyetemi oktatás, a kutatóképzés új „terepévé” is előlépett.

A program kezdetekor megfogalmazott kutatási irányok, témák, a kutatás módszerei alapvetően a hazai mongolisztikai kutatások hagyományain alapultak, de a rendszeres terepmunka alatt szerzett tapasztalatok révén, illetve a projektben részt vállaló korábbi diákok közül tudományos fokozatot szerzett fiatal kutatók csatlakozásával fokozatosan kibővültek. A levéltárakban, magángyüjteményekben őrzött történeti, vallástörténeti források feltárásával a program kiemelt része lett az archívumi kutatás is, melynek vezetői 2004-től elsősorban Bethlenfalvy Géza és Szilágyi Zsolt lettek. ${ }^{24}$ A programban kezdetektöl hangsúlyos szerepet kapott a rendszerváltás után újjáéledő modern mongol buddhizmus kutatása is, melyben Majer Zsuzsa és Teleki Krisztina csatlakozásának köszönhetően egyre hangsúlyosabb szerepet kapott a mai kolostori élet dokumentálása. ${ }^{25}$

Az elmúlt években sok tekintetben változott az expedíció munkája. Új kutatók csatlakozása gyakran nemcsak a kutatási témák számát, de a vizsgálat szempontjait is bővítette, a mongolisztikai alapok mellett megjelentek más rokon tudományágak vizsgálati szempontjai is, de a kutatási tevékenységre a legnagyobb hatással mégis a vizsgálat tárgyának, a mongoloknak, a mon-

megvalósítani, melyeknek jelen cikk szerzője résztvevő szenior kutatója volt. Nagy segítséget jelent, hogy az OTKA a mongóliai kutatásokat egyéni pályázatok - pl. a szerzö K 68673 és K 109043 programjai - keretében is támogatja.

23 Az expedíció addigi történetét bemutatta Birtalan 2008, melyet részben kiegészített egy későbbi idegen nyelvü publikációval (Birtalan 2012).

24 Az archívumi kutatások eredményeinek publikálására jött létre a Treasures of Mongolian Culture and Tibeto-Mongolian Buddhism című sorozat, melynek keretében eddig öt kötetben és két CD-kiadványban láttak napvilágot régi és ritka tibeti, illetve mongol nyelven íródott kéziratok, fanyomatok fakszimile kiadásai.

25 A 2000-es évek elején végzett kutatásaikról részletesen lásd www.mongoliantemples. org (utolsó megtekintés: 2018. január 12.). 
gol társadalomnak és kultúrának az átalakulása volt. A „terep” megváltozott, és ez alapvetö hatással volt az expedíció tevékenységére is.

\section{A kutatás új ,terepe"}

Az ezredforduló sok tekintetben hozott új fordulatot Mongólia életében. A korábban vázolt folyamat, mely a városi népesség lélekszámának csökkenését - egyúttal a nomád pásztorok számának emelkedését - okozta, két jól körvonalazható ok miatt megtorpant. Az egyik a nomád életmóddal, a másik jóval inkább a globális piaci környezettel kapcsolható össze.

A nomád körülmények között a pásztorok és a megélhetésüket biztosító állatállomány meglehetősen kitett a mostoha természeti körülményeknek. A legelőterület eltartó képessége korlátozott, csak kevés helyen van lehetőség a téli takarmány gyüjtésére - jellemzően csak Mongólia északi területein, Hövszgöl megyében (halha Xöwsgöl aimag) tartanak kaszálókat (halha xadlan) -, így egy-egy szárazabb nyár kevésbé dús legelői nem tudják felkészíteni az állatállományt a zord télre. A jelentős mértékben megnövekedett állatállományt a gyakran előforduló téli állatpusztulás (halha jud) lokálisan még nagyobb mértékben sújthatja. Gyakran egy-egy pásztorcsalád teljes állatállománya elpusztul, aminek következtében sokan megélhetésüket elveszítve kénytelenek elhagyni legelöiket és a városokba költözni.

Ezzel párhuzamosan az 1990-es évek végére a mongol gazdaság is kezdett fokozatosan magára találni. Az inflációt sikerült kontrollálni, a makrogazdasági környezet kedvező volt, a kereskedelmi és szolgáltató szektor fejlödése egyre látványosabb volt, és megindult egy stabilnak tekinthetö GDPnövekedés (2003: 7\%, 2004: 10.6\%). ${ }^{26} \mathrm{Az}$ újonnan létesülő munkahelyek könnyedén felszívták a vidékröl érkező munkaerőt, így a vidéki életmódjukat kényszerüségből feladók mellett egyre többen választották önszántukból is a városi életet.

A városi élet alapvetően új kulturális környezetet is teremtett a betelepülők számára. Sokan nehezen birkóztak meg az e körülmények támasztotta elvárásokkal. Még akkor is így van ez, ha kijelenthetö, hogy a fövárost célpontjuknak tekintő migránsok jelentős része a megyék (halha aimag) és járások (halha sum) központjaiból költözött a fövárosba, és csak kevesebben

26 Shi 2011: 7. 
közvetlenül a pusztákról. ${ }^{27} \mathrm{~A}$ városi élet alapvetően más ritmust követel, egy piacgazdasági környezetben dolgozó ipari létesítmény vagy más munkahely alapvetően eltérő rendszerességet visz a mindennapokba, mint a nomád környezet. A korai 2000-es évek egyik visszatérö problémája volt, hogy nem találtak megfelelő munkaerőt a fóvárosban zajló ingatlanfejlesztések építkezéseire. Bár jelentős létszámú - akár képzetlen - munkaerőt is képesek lettek volna ezek a tevékenységek felszívni, a jellemzően kínai befektetők által finanszírozott építtetők inkább külföldi munkásokat alkalmaztak, mert a mongolok gyakran nem tudtak alkalmazkodni az itteni elvárásokhoz, például a kötött munkaidőhöz. ${ }^{28}$

A felmerülő konfliktusok ellenére az elmúlt két évtizedben a föváros lélekszáma folyamatosan nőtt még akkor is, ha az ulánbátori lakosság növekedésének üteme látszólag csökken, az 1989-2000 közötti 44,6\%-ról 20002007 között 31,1\%-ra esett. ${ }^{29}$

Ez a változás azonban a teljes mongol lakosságra vetítve óriási. A rendszerváltás idején a fővárosban a mongol népességnek alig egynegyede élt, a 2010. évi népszámlálás idején viszont már több mint 1,2 millió fö, az ország lakosságának több mint 45\%-a élt itt, és az urbanizáció mértéke 67,9 százalék volt. ${ }^{30} \mathrm{~A}$ város lakosságának száma az elmúlt öt évben is folyamatosan emelkedett, napjainkban jóval meghaladja az 1,3 millió föt. Emellett ez a rendkívül gyorsan lezajló urbanizáció és belső migráció Mongóliában egybeesett a másfél-két évtizeddel ezelött még csak nyomaiban megfigyelhető globalizáció hatásaival is. Ennek következtében ma a fövárosban élő népesség a vidékitől markánsan eltérő kulturális mintákat követ, melyben a mongol identitás, a hagyományos nomád szemlélet csak egy elem, s ez keveredett a nyugatról - ebben a térségben koreai vagy japán közvetítéssel, tehát keletről érkező kulturális mintákkal. Ez a változás a cikkünk elején felvázolt kutatási irányokat, a kutatás „terepét” alapvetően más irányba terelheti, illetve korábbi elképzeléseinket, tapasztalatainkat más megvilágításba helyezheti.

27 Shi 2011: 11.

28 Szilágyi 2010b: 333.

29 Shi 2011: 29.

30 Mongol Statisztikai Hivatal 2012 (halha Mongoliin Ündesnii Statistikiin Xoroo, http:// www.nso.mn/index.php, utolsó megtekintés: 2017.11.14). 


\section{A kettészakadt mongol társadalom}

A piacgazdaság bevezetése óta Mongóliában is jól érzékelhető, hogy az egyes társadalmi csoportok jövedelme, életszínvonala között folyamatosan nő a különbség, de az alcímben jelzett kettősséget itt elsősorban kulturális, és nem gazdasági értelemben használjuk. A fentebb vázolt gazdasági, társadalmi változások következtében az elmúlt másfél-két évtizedben Mongóliában fokozatosan alakult ki két azonos kulturális hagyományokat magánénak valló, de a mindennapi életvitelét, kulturális preferenciáit tekintve markánsan elkülönülő társadalmi csoport. A kialakult új kulturális környezet más és más mértékben hatott a vidéki és városi lakosságra, $\mathrm{s}$ ennek köszönhetően az egyes csoportok alkalmazkodási stratégiája is más lett.

A vidéki népesség túlnyomó többsége ma is a hagyományosnak tekinthető nomád legelőváltó gazdálkodás keretein belül éli életét. A modernizáció nyújtotta lehetőségeket fokozatosan építi be mindennapjaiba, de ezek alapvetően nem szervezik át az életvitelét, változást elsősorban az eszközhasználatban figyelhetünk meg. A motorizáció hatása már nemcsak a városokban érzékelhetö, de vidéken is lépten-nyomon találkozhatunk vele. ${ }^{31} \mathrm{~A}$ jószágot már gyakran nem lovon, hanem motoron ülve terelik, az évszakonkénti legelőváltáskor, költözéskor már inkább teherautókat használnak; a teherhordó állatok kevésbé játszanak szerepet, s egyre gyakrabban találkozhatunk olyan nomád szállásokkal, ahol nem látunk ilyeneket. Bár a hétköznapi életben például a motor fokozatosan kezdi átvenni a lovak szerepét, ugyanakkor ezek eltünésétől, a lóállomány számának drasztikus csökkenésétől nem kell tartani, hiszen birtoklásuk alapvetően összefügg a mongol hagyományokkal, a nomád mongol identitás része.

A modernizáció vidéken egyre gyakrabban tetten érhető másik példája, hogy a jurták mellett mind több helyen figyelhető meg egy-egy napelem vagy kisebb teljesítményü szélgenerátor. Az ezekkel termelt áram elsősor-

31 Mongóliában 1998-ban a 36700 nyilvántartott gépkocsi közül 23800 volt magántulajdonban. Ez a szám 2012-re 228 952-re, illetve a magántulajdon tekintetében 177 522re nőtt, ami hét és félszeres növekedést jelent. Lásd http://www.fukuoka.unhabitat.org/ kcap/activities/egm/2013/pdf/egm15_en.pdf, https://www.adb.org/sites/default/files/linked-documents/39256-023-mon-ssa.pdf, utolsó megtekintés: 2017.11.14). 
ban a tévé, rádió müködtetését szolgálja, de napjainkban gyakori példa, hogy a jurta tetőtartó rúdjai alatt már egy-egy mobiltelefont is találunk. ${ }^{32}$

E körülmények a nomádok mindennapi életét ugyan kevéssé befolyásolják, de az infokommunikációs eszközök, a tévé és online média elérhetőségének lehetősége a fiatal vidéki népesség életmódjára, hosszabb távú egzisztenciális terveire jelentős hatással van. Ma a vidékről a városias települések, megyei központok, és még inkább a főváros felé irányuló migráció jelentős részét nemcsak a munkát kereső népesség, de a városokba tanulni induló fiatalok teszik ki. Mivel a Mongóliában elérhető több mint másfélszáz felsőoktatási intézmény $64 \%$-a fövárosban található, ${ }^{33}$ az itt elérhető edukációs lehetőségek miatt sok vidéki fiatal költözik Ulánbátorba, akik tanulmányaik befejezése után már nem térnek vissza a nomád környezetbe.

A folyamatban a vidéki népesség csökkenése mellett még egy negatív folyamat is megfigyelhetö. A felsőoktatásban egyre jelentősebb a nemek közötti eltérés a nők javára. A nomád körülmények között a fiatal férfiak általában korán a család férfi tagjai mellé szegődnek az állatokkal kapcsolatos munkák elvégzésére. Munkaerejük nehezen nélkülözhető, ezért jóval kisebb esélyük van arra, hogy a nomád életmódot feladva a városba költözzenek. Ma a felsőoktatásban a nők aránya nagyjából másfélszerese a férfi hallgatókénak, s ez a tendencia a 2000-es évek második felétől kezdődően jól megfigyelhetö, és mértéke szignifikánsan nem csökken. ${ }^{34}$ Ennek köszönhetöen a fiatal mongol népesség magasan kvalifikált rétegében fokozatosan növekszik a nők túlsúlya, a nemek közötti arány felbomlik, és fokozatosan kulturális értelemben is eltávolodnak egymástól.

A fiatal városi lakosság számára a nomád hagyományok egyre kevéssé kézzelfoghatóak. Az általuk követett kulturális minták egyértelmủen a globalizáció túlsúlyát mutatják, ugyanakkor határozottan érezhető, hogy a mongol identitás egyik alapját még mindig a nomád kultúra adja, bár ez a városi életben elsősorban formális helyzetekben érhető tetten. Az öltözködésben csak ünnepi alkalmakkor kerül elő a hagyományos viselet, bár egyre

32 Az infokommunikációs technológia tekintetében Mongólia a regionális rangsorban csak két hellyel lemaradva követi a mindenhol példaként emlegetett Kínát, és olyan országokat előz meg, mint Irán vagy Vietnám. Ma csaknem másfél millió mobilelőfizető van az országban, ami azt jelenti, hogy a lakosság fele eléri ezeket a szolgáltatásokat (Batbayar 2015).

33 Adiya 2010: 6.

34 Adiya 2010: 7. 
gyakrabban tapasztaljuk, hogy a díszes mongol dél (halha $d \bar{e} l$ ) mellé a férfiak stetson kalapot választanak, ami korántsem tekinthető a hagyományos viselet elemének. Ennek ellenpontjaként fokozatosan egyre népszerübbek a hagyományos mongol viselet egyes elemeit, ékszereit, a mongol motívumkincset használó és azt a nemzetközi divattrendeknek megfelelö köntösben bemutató fiatal mongol képzőmüvészek, tervezők (B. Bayarmā, B. Očirjancan).

Érdekes, hogy miközben a városi lakosság fokozatosan eltávolodik a hagyományos életmód mindennapjaitól, a mongol kézműves hagyományok, az ezzel foglalkozó mesterek presztízse folyamatosan nő. Erre jó példát láthattunk, amikor 2017-ben a budapesti Mesterségek Ünnepe rendezvényen mongol kézmúvesek voltak a díszvendégek. Jelen sorok írója az egyik szervezője volt az eseménynek, melynek kapcsán hosszabb időt tölthetett mongol mesterekkel, ijkészítővel, kovácsokkal, textilművészekkel. ${ }^{35}$ A kézmüvesekkel folytatott beszélgetések, a mongol Kulturális Örökség Központban (halha Soyolīn Öwīn Töw) lezajlott konzultációk, illetve a hazai rendezvényen szerzett tapasztalatok alapján sajátos kép alakult ki e hagyományos mesterségek továbbélésével, a hagyományőrzéssel, a nomád kézmüves hagyományok mongóliai megbecsülésével kapcsolatban.

E tevékenység adminisztratív feltételei nagy vonalakban már 1988-tól adottak voltak Mongóliában, hiszen ekkor jött létre a mai központi szervezet elödje. Bár nincs olyan részletesen kidolgozott mechanizmus, mint azt a nyugati országokban - így például hazánkban is - megfigyelhetjük, az alapokat már a rendszerváltás utáni időszak korai szakaszában letették. Az országban 1990. február 2. óta müködik UNESCO Nemzeti Bizottság, ${ }^{36}$ és 1994-től törvényi háttérrel müködik a Kulturális Örökség Központ. 2008-től a nem kormányzati háttérrel müködő szervezetekkel is felvették a kapcsolatot, létrejött a Szellemi Kulturális Örökség Nemzeti Központja. ${ }^{37}$ Ennél jelen témánk szempontjából talán érdekesebb, hogy miként alakul ennek a tevékenységnek a szerepe, presztízse a mongol mindennapokban.

A nomádok hagyományos életkörülményeik között sok tekintetben önellátóak voltak, eszközeiket, szállásukat gyakorta saját erőből, önmaguk készítették, mozgékonyságuknak, alkalmazkodó képességüknek ez volt az egyik záloga. Voltak azonban mesterségek - így például a kovácsoké -, melyeket

35 http://www.mestersegekunnepe.hu, utolsó megtekintés: 2017.12.15.

36 http://whc.unesco.org/en/statesparties/mn, hu, utolsó megtekintés: 2017.11.19.

37 http://www.mongolheritage.com, utolsó megtekintés: 2017.12.11. 
kiemelt figyelem, gyakran tisztelet övezett. E hagyományok megtartása ma, a modernizálódó és globalizálódó Mongóliában - és talán nem meglepő módon elsősorban a robbanásszerüen átalakuló urbanizálódó környezetben - különösen fontos. A vidéki hagyományos körülmények között ez egyes mesterségek, a kézmüves tevékenység sok tekintetben a múltban betöltött szerepét őrzi, a városokban, ahol az ott élők már nem önellátásra rendezkedtek be, azonban alapvetően más szerepet játszik. A különlegesen aprólékosan, gyakran drága alapanyagokból készített kézmüves termékek - textilek, ötvösmunkák, lakberendezési tárgyak - elsősorban nem használati funkciókat betöltő eszközök, hanem különleges anyagi és eszmei értékkel is bírnak. Ehhez mérhető a presztízsük is, melyet leginkább a magyar szemnek is meglepően magas áraik jeleznek. A hazai kézművesség immár 31. alkalommal megrendezett nemzetközi évi seregszemléjén a mongol mesterek termékei jóval magasabban árazottak voltak, mint a hasonló hazai kézműves remekek.

Magyarországon a népi kézmüvesség termékei általánosan elérhetőek, és bár használatuk, viseletük kifejezhet egyfajta identitást, de árukat mégis inkább jórészt a „piac” szabályozza. Ezzel szemben Mongóliában egyrészt érezhető a kézi erővel végzett kivitelezés rendkívüli megbecsülése, másrészt a hagyományos technológiával, hagyományos motívumkinccsel készített tárgyak, eszközök identitást jelző szerepe is. Ennek köszönhetően például a Mesterségek Ünnepén az volt a tapasztalat, hogy a mongol mesterek által - otthoni tapasztalatok alapján - kalkulált árak a magyar vásárlók számára megfizethetetlenek voltak, annak ellenére, hogy utóbbiak jobb gazdasági körülményeiknek köszönhetően jóval nagyobb vásárlóerővel rendelkeznek, mint a mongolok. Egy mongol íjkészítő által hagyományos technológiával, csaknem egyéves munkával készített íj egy magyar hagyományőrző íjász számára már szinte megfizethetetlen - elsősorban a befektette kézimunka ára miatt. Miközben pedig itthon a hagyományos íjászatot, a lovasíjászatot folytatók jelentős része nem csupán annak sportértéke, hanem egyfajta „hagyományőrző", identitásjelző szerepe miatt is folytatja ezt a tevékenységet. Erre a hozzáállásra akár brand is épülhet, természetesen a megfelelő gazdasági környezet, a megfelelő befektetés-jövedelem aránypár kialakítása után. Mongóliában ilyet (még?) nem tapasztalhatunk. Egy mongol íjász kezében nem láthatunk a tömeggyártás technológiájával olcsóbbá tett eszközt, hiszen e hozzáállásban a gazdasági megfontolásoknál jóval fontosabb szerepet játszik a hagyomány tisztelete, az identitás szerepe. Ilyen, mikor egy még élő hagyományt viszünk tovább. 
Hasonlót tapasztalhattunk a textilművészek munkáinál is. Egy aprólékos gonddal hímzett mongol csizma, ruha, de még egy Dzsingisz képmását ábrázoló mongol falikép esetében is a befektetett munka, a hozzáértés, a hagyományos technika és motívumkincs mind-mind olyan összetevő, mely nem csupán a kiemelkedő mesterségbeli tudás miatt emeli a tárgy értékét, hanem a hagyománytisztelet miatt is. A mongol kézmúvesek látogatásának egyik fontos tanulsága az volt, hogy a mongol vendégeink nehezen értették, itthon milyen szerepe, presztízse van a magyar kézmüves termékeknek, hogyan viszonyul hozzájuk a vásárló, de akár a gyártójuk is, a hagyományos nemzeti kultúra megőrzésében milyen szerepet játszanak.

Mongóliában markáns változás figyelhető meg az urbanizált környezetben élők mindennapi életének számos területén, így például az étkezéseikben is. A hagyományos nomád körülmények között a szükös alapanyagok, az egyszerü eszközök, a füszerek hiánya miatt sohasem alakulhatott ki olyan sokszínü gasztronómiai kultúra, mint a letelepült társadalmakban. Itt is elsősorban a praktikus szemlélet érvényesült, a nomádok gyorsan elkészíthető tápláló ételekre vágytak, főzési technikáik, a használt eszközök mindig egyszerúek. Fontos számukra a jó eltarthatóság, amit általában szárítással oldottak meg. Étkezéseikben megfigyelhető egyfajta lazán vett ciklikusság, nyáron inkább tejes, télen inkább húsból készült ételeket fogyasztanak.

A városi környezet azonban már megteremti az alapvetően a letelepült társadalmakra jellemző feltételeket is. Az alapanyagok jóval szélesebb skálája érhető el, adottak a különböző főzési, sütési technológiák, és jóval változatosabb külső impulzusok is érik az itt élő embereket. Az elmúlt 10-20 évben Ulánbátorban érezhetö, hogy a mongolok étkezési szokásai kevésbé, ízlésük azonban nagyon gyors ütemben változott. Egyre többen fogyasztanak a nomád körülmények között korábban elérhetetlen zöldségeket, megkedvelték a mongol ízlés számára elfogadhatatlanul füszeres kínai, indiai, koreai konyhát, és ezek hatására a hagyományosnak tekinthető mongol ételek is átalakultak. Miközben megmaradt a húsfogyasztás dominanciája egy mongol számára az ünnepi asztal, de a mindennapi laktató étkezés is elképzelhetetlen valamilyen húsos fogás nélkül -, ma már olyan nemzeti éte-

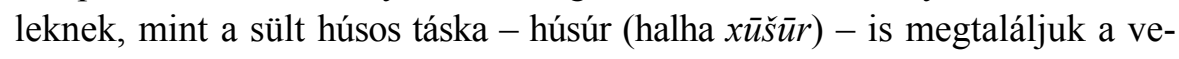
getáriánus változatát. Ez húsz évvel ezelőtt elképzelhetetlen lett volna.

Ugyanakkor akárcsak a divatban, itt is találunk példákat arra, hogy egyes termékek, szolgáltatások népszerüsítésekor külön hangsúlyozzák azok nomád hagyományokban gyökerező, azokra emlékeztető jellegét, miközben 
alapvetően a globalizált kultúrából érkező impulzusokra, mintákra reagálnak. Mindnyájan találkozunk azzal a jelenséggel, amikor egyes termékeket a tömegtermeléssel gyártott áruk között azzal reklámoznak, hogy kézzel készült, egyedi termékek. 2016 nyarán a mongol fövárosban az ikonikus Nagy Áruház (halha Ix delgür) előtt egy olyan - Empire khuusuur fantázianévre hallgató - büfét fényképezhettem, ahol azzal hirdették az itt készült termékek minőségét, hogy azok bizony kézzel készültek. Aki ismeri a hagyományos ételek elkészítési módjait, az tudja, hogy a mongolok nemzeti eledelének tartott sült húsos táska másképpen nemigen készülhet - jelen sorok írója még nem találkozott futószalagon készült változatokkal -, így itt tipikusan azzal a helyzettel találkozhattunk, hogy az új környezet szabályainak megfelelően, az ott érvényes érvrendszerben próbálják a hagyományos terméket megjeleníteni.

A városi lakosság bizonyos esetekben már ünnepeiben is csak a formalitás szintjén utal nomád hagyományaira. Miközben a legjelentősebb mongol családi ünnep a Holdújév (halha cagān sar) jórészt - a felszolgált ételek, a családon belüli vendéglátás, a családok és barátok köszöntése stb. tekintetében - megőrizte eredeti formáját, más családi ünnepekre, például az esküvői szokásokra markánsan rányomta a bélyegét az új kulturális környezet. Ez természetesen összefügg azzal, hogy az esküvő általában az újdonságra - jelen esetben a globalizált kultúrára - jóval fogékonyabb fiatal nemzedék meghatározó ünnepe. Miközben vidéken napjainkban is gyüjthetünk hagyományos esküvői szertartásokat, addig a városi környezetben a mongol kultúrában hagyományosnak egyáltalán nem tekinthető fehér esküvői ruha, a gyürü, a koszorúslányok hada a jellemzö, tipikusan nyugati mintákat követve. Ugyanakkor mégis megfigyelhetőek a mongol identitásban gyökerező, de alapvetően újonnan hagyománnyá - vagy divattá - váló szokások, például az, hogy minden Ulánbátorban - vagy a közeli területeken - egybekelő pár elzarándokol a felújított parlament épülete előtt található Dzsingisz-szoborhoz, és ott készíti el közös esküvői fotóját. Ez az aktus manapság már elhagyhatatlan részét képezi egy városi esküvőnek.

A hagyományos nomád értékek és életmód reprezentációja a városi népesség körében folyamatosan változik. Az élet számos területén megfigyelhető a nomád kulturális hagyomány tudatos használata, ugyanakkor a vidéki életmód elemei erősen keverednek a globalizáció kulturális hatásaival. $\mathrm{Az}$ életvezetésben jól érzékelhetően érvényesülnek bizonyos kulturális minták, melyek a hagyományos nomád kultúrához köthetőek. A tradicioná- 
lis nomád ökológiai szemlélet - jóllehet ez sokat degradálódott az utóbbi években -, a hagyományos vendégszeretet, az őszinteség mind-mind a hagyományos mongol nemzeti kultúra mindenki által emlegetett jellemzői, melyeket a városi lakosság is magáénak vall. Azonban egyre gyakrabban találkozhatunk a vidéki (halha xödönī) és a városi (halha xotīn) kategóriák szembeállításával is. Ezeket gyakran egymással ellentétes fogalmakként kezelik, ahol a vidéki inkább az elmaradottság, a városi pedig a modernség szinonimája, miközben ez a fogalomhasználatban is ellentmondásokat szül, hiszen, mint említettük, a „vidéki élet”, a hagyományos kultúra sokszor identitásképző erejénél fogva pozitív értékü jelentéstartalommal is bírhat.

\section{Az ,úuj” terep}

A fenti példák is jól bizonyítják, hogy az elmúlt másfél évtizedben a mongol társadalom olyan markáns változáson esett át, amely új kutatási terepet is jelenthet egy a mongol kultúrával foglalkozó program vagy kutató számára. Ez nem jelenti feltétlenül alapvetően új kutatási témák bevezetését, de mindenképp fontos lehet a kutatási koncepció, a metodológia kialakítása szempontjából. Ugyanakkor az új környezetre adott reakciók a korábbi kutatások alapján levont következtetéseket is módosíthatják. Alább csak egy példát szeretnék említeni ezzel kapcsolatban.

Már többször utaltunk rá, hogy az eddig folyó program egyik kiemelt témája a valláskutatás. Az 1990-es évek elején a mongol vidék jó terepet biztosított a sámánizmus, de az újjáéledő buddhizmus kutatásához is. A sámánizmus, a népi vallásosság tekintetében egyértelmüen könnyebb volt a nomádok között terepmunkát végezni, míg a buddhizmus tekintetében a városi környezet nyújtott több lehetőséget a kolostorok újjáépítésére, így itt sokkal látványosabb ütemben történt az egyház újjáéledése, gyorsabban gyarapodott a kolostorok, a lámák, de a szertartásokon részt vevő hívek száma is.

Az első évtizedben úgy tünt, az kolostorok újraalapítása, újjáépítése tekintetében a vidék sem marad le a föváros mögött. Egyrészt a nomád szállások házi oltárain egyre gyakrabban jelentek meg - gyakran a kolostorrombolások idején elrejtett - buddhista kegytárgyak, megindult a hagyományos vidéki buddhista központok újjászervezése. A szerencsésebbnek mondható területeken még egy-egy idősebb láma is élt azok közül, akik már az 1930as években is lámák - lámatanoncok (halha band') - voltak. Közremüködé- 
sükkel indulhatott meg az egyes kolostorok újjászervezése. A kezdeti lelkesedés azonban hamar megtorpant, hiszen az egyházi oktatási rendszer a pusztítás után több mint fél évszázadon keresztül nem müködött, így nem voltak olyan lámák, akik a hagyományos képzési rendszer keretei között kaptak olyan beavatást, amely a kolostorok vezetésére predesztinálta volna öket. A fiatalokat el kellett küldeni tanulni.

A mongol buddhista oktatási rendszer hagyományos keretek között történő újjáépítése már a kilencvenes évek közepén megkezdődött. Ez a tevékenység azonban alapvetően a városokhoz köthető, ami azt eredményezte, hogy a vidéki fiatalok városi - elsősorban fővárosi - kolostoriskolákba (halha dacan) mentek tanulni, a vidéki kolostorok elnéptelenedtek. Ez óhatatlanul együtt járt az egyház befolyásának csökkenésével, ami a mai napra meglepő méreteket öltött. A magát többségében buddhistának valló vidéki mongolság között a lámák presztízse jelentősen romlott, és ez a tendencia megfigyelhető a szertartásokra ritkábban járó városi lakosság körében is. A vallásszabadság kezdeti eufóriája után a buddhista egyház fokozatosan eltávolodik a vidéki lakosságtól, a mai mongol társadalomban betöltött szerepe átalakul.

Ma a városi népesség körében tapasztalható, hogy azoknak a kolostoroknak, vezető lámáknak van igazán nagy tekintélyük a hívek között, melyek és akik láthatóan jóval gazdagabbak az átlagnál. Az épületek újak, a lámák jó autókkal járnak, aranyórát viselnek stb. Ez a szemlélet látszólag szemben áll a vináya alaptanításaival, mégsem jelent problémát a híveknek, akik elvileg elvárják a buddhista tanítások betủ szerinti követését a beavatott lámáktól. A nomád körülmények között a zord életkörülményekkel szembeni túlélés kényszere vezette az embereket, ezért a mongol kulturális hagyományban nagyon mélyen gyökeredzik, hogy mindig a sikeres életvitel, a rendelkezésre álló lehetőségek minél jobb kihasználása jelenti a követendő példát, legyen szó sikeres hadvezérről, gazdag pásztorról, sikeres vállalkozóról vagy kolostorát jól vezető lámáról.

A mongol rendszerváltás utáni időszakot jellemző vallási türelem elsősorban a városokban alapvetően új kihívások elé állította a buddhista egyházat, új riválist hozott az „új piaci környezethez” jól alkalmazkodó, a városokba költöző és ott széles pacientúrát kialakító sámánoknak. S már az 1990-es évek elején megjelentek a keresztény egyházak, kisebb felekezetek, amelyek jelentős energiákat mozgósítottak a térítés érdekében. A mormonok vagy a Dél-Koreából érkező keresztények ösztöndíjakkal, külföldi munkavállalás lehetőségével viszonylag könnyen tudták motiválni az 
új híveiket, akik gyakran egzisztenciális okokból csatlakoztak ezekhez a közösségekhez. A magukat kereszténynek vallók aránya ma nem tekinthető jelentősnek, 2,2\%, ${ }^{38}$ alig tér el a 3 százaléknyi muszlim lakosságétól, ${ }^{39}$ mégis a kereszténység sokkal kézzelfoghatóbban jelen van a mindennapi életben, mint az iszlám. Egyre-másra épülnek a keresztény templomok a mongol fővárosban, de vidéki városokban, például Erdenetben is. Sokan meglehetősen negatívan állnak ehhez a jelenséghez, a mongol hagyományoktól teljesen idegennek tartják, sőt kongatják a vészharangot, féltik a mongol buddhizmust, a hagyományos mongol kultúrát, miközben a keresztények számát a hivatalos vizsgálatokon vagy a 2010. évi népszámláláskor mért adatoknál is jóval magasabbnak tartják.

Ugyanakkor kutatóként azt is tapasztalhatjuk, hogy a kereszténységgel kapcsolatba kerülő, de nem megtért mongolok a mindennapi életben mintha kisebb jelentőséget tulajdonítanának a kereszténység térnyerésének. Adott esetben az új vallás(ok) megjelenését nem tekintik másnak, csak a transzcendenssel, a felső világgal való kapcsolatteremtés egyik módjának. Megközelítésükben könnyủ az átjárás a keresztény templom, a buddhista kolostor és egy sámánszentély között. Mindegyiket „használják”, a cél a szakrális igény kielégítése, amihez minden adódó lehetőséget ki lehet használni, hiszen minden út „egy irányba vezet”.

Azt már korábban a vidéki népesség körében is megfigyelhettük, hogy a mongol népi vallásosságban, a buddhizmusban, de a sámánhagyományokban is nagy szerepe van a szinkretizmusnak. Sámánok használnak buddhista eszközöket, néha szövegeket is, buddhista szertartásoknak, szenteknek vannak sámánhagyományra visszavezethető elemeik. ${ }^{40}$ Konszenzusos tény, hogy a buddhizmus a tibeti és belső-ázsiai elterjedése során azért volt olyan sikeres, mert alapvetően türelmes, befogadó vallás, könnyen olvasztja be az új területeken korábban meglévő vallási hagyományok elemeit. Ma a mongol városokban tapasztalható vallási sokszínüség még egy új lehetőséget is felvet, amin talán érdemes elgondolkodni. Lehetséges, hogy a nomádok vallásossághoz való pragmatikus hozzáállása is hozzásegítette a buddhizmust ehhez a sikeres terjeszkedéshez. Ahogyan napjainkban a kereszténységet,

38 http://www.slideshare.net/Ochiro/mongolia-2010-population-census-main-findings (utolsó megtekintés: 2016. október 14).

39 http://www.slideshare.net/Ochiro/mongolia-2010-population-census-main-findings (utolsó megtekintés: 2017. december14).

40 Birtalan - Kelényi - Szilágyi 2010. 
korábban talán a buddhizmust „használták” hasonló módon. A vallásra eszközként tekintenek, mely lehetővé teszi a természetfeletti világgal való kapcsolattartást.

Bár Mongóliát etnikailag sokkal egységesebb területként kezelhetjük, mint bármely szomszédját a térségben, érdekes tapasztalni, hogy a rendszerváltás utáni környezetben újra és újra felszínre kerülnek a nemzetségi kérdéssel kapcsolatos viták. Ez a városban éppen úgy megfigyelhetö, mint vidéken, szerepe azonban adott környezetben más és más lehet. A fokozatosan formálódó, elsősorban a nomád hagyományokra, a buddhizmusra alapuló nemzeti identitás mellett bizonyos területeken egyes népcsoportoknál egyfajta lokális identitás megerősödését is megfigyelhetjük. Ez nemcsak a városi-vidéki viszonyban jelenik meg, ${ }^{41}$ és a vidéki pásztorok és a városiak konfliktusára utal, de adott vidéki népesség egyes csoportjai között is. Érezhető, hogy ebben a kontextusban fokozatosan elválik a mongol nemzeti identitás fogalma (halha ündesten) a nemzetségi (halha yastan) fogalomtól, ${ }^{42}$ és adott kontextusban ez utóbbinak is komoly szerepe lehet. Adott környezetben, vidéki terepmunkáink során egyre gyakrabban találkozhatunk olyan helyi adatközlőkkel, akik gyakran önszorgalomból foglalkoznak az adott járás, az adott népcsoport történetével, hagyományaival, és így nem feltétlenül életkoruk, inkább tudatos tanulás során szerzett tájékozottságuk miatt válnak jó, adott esetben „hivatásos” adatközlőkké. 2016-os hotogojt (halha xotgoid) területen, Hövszgöl megye déli részén végzett terepmunkám során Cecerleg járásban (halha Cecerleg sum) találkozhattam C. Lhagvával (halha Cuuriin Lxagwa), aki mezögazdasági gépésztechnikusként, kedvtelésből kezdett foglalkozni a hotogojtok történetével, kulturális hagyományaival. ${ }^{43}$ Tevékenységére immár az egész helyi közösség büszke, az Ulánbátorból vagy külföldről érkező kutatók felé ő a helyi közösség képviselője, munkáját az adminisztráció helyi vezetői is támogatják. Tevékenységével a helyi közösség összetartását erősíti, akik mongolságuk mellett egyre határozottabban hivatkoznak sajátos kultúrájukra, annak mongol hagyományoktól való eltéréseire is.

A fentiekben csak néhány olyan témát villantottunk fel, amelynek kapcsán az új környezet, az „új terep” a korábban gyüjtött adatok értelmezésé-

41 Szilágyi 2010b.

42 Szmyt 2012.

43 J̌agwa 1997. 
nek új lehetőségét is nyújthatja. A 25 éve vidéken elkezdett terepmunkát folytatni kell, hiszen épp az elmúlt évtizedek gyors változásai bizonyították, hogy a hagyományos nomád életforma, a hagyományos terep eltủnőben van. Az ott gyüjtött tapasztalatok azonban sokat segíthetnek nekünk az új mongol kultúra megértésében és megismerésében is.

\section{Másodlagos szakirodalom}

Adiya, Enxjargal 2010. Gender Equity in Access to HigherEducation in Mongolia. ( $\mathrm{PhD}$ diss., University of Pittsburg, http://d-scholarship.pitt.edu/8631/1/enkhjargaladiya.pdf, utolsó megtekintés: 2016. október 12.)

Algaa, Solongo 2007. Growth of Internal and International Migration in Mongolia. (Paper presented at the Migration, Development and Poverty Reduction. $8^{\text {th }}$ International Conference of Asia pacific Migration Research network, May 25-29, 2007, Fuzhou, China. http://apmrn.anu.edu.au/conferences/8thAPMRNconference/6.Sologo. pdf, utolsó megtekintés: 2017. november 10.)

Avar Ákos 2014. A természet és az állatok a hagyományos mongol gondolkodásban. Budapest: Equinter Kiadó.

Bakó Boglárka 2004. „A terepmunka értelmezése, avagy az etikusság határán.” Kisebbségkutatás 2004/3:388-394. (Online elérhetőség: http://www.hhrf.org/kisebbsegkutatas/ kk_2004_03/cikk.php?id=8,http://epa.oszk.hu/00400/00462/00023/pdf/terep03.pdf (utolsó megtekintés: 2017. szeptember 12.)

Batbayar, V. 2015. Satellit communication in Mongolia. (https://www.itu.int/en/ITUD/Regional-Presence/AsiaPacific/Documents/Events/2015/October-IISS-2015/ Presentations/S4_Batbayar_Vandansambuu.pdf, utolsó megtekintés: 2018. január. 11.)

Birtalan Ágnes (szerk.) 1996. Tanulmányok a mongol népi hiedelemvilágról. [Öseink nyomán Belső-Ázsiában I.] Budapest: Nemzeti Tankönyvkiadó.

Birtalan Ágnes (szerk.) 1998. Hitvilág és nyelvészet. [Öseink nyomán Belső-Ázsiában II.] Budapest: Nemzeti Tankönyvkiadó.

Birtalan Ágnes (szerk.) 2004. Helyszellemek kultusza Mongóliában. [Öseink nyomán Belsö-Ázsiában III.] Budapest: Új Mandátum Könyvkiadó.

Birtalan Ágnes 2008. „A magyar-mongol nyelvjárás- és népi műveltségkutató expedíció tevékenysége." Vallástudományi Szemle 2008/1: 197-208.

Birtalan, Ágnes 2012. „Fieldwork among the Oirats. Activity of the Hungarian Mongolian Joint Expedition for the Research of Mongolian Dialects and Traditional Culture." In: Ágnes Birtalan (ed.) Oirad and Kalmyk Linguistic Essays. Budapest: ELTE Eötvös Kiadó, 11-24.

Birtalan Ágnes - Kelényi Béla - Szilágyi Zsolt (szerk.) 2010. Védelmezö istenségek és démonok Mongóliában és Tibetben. [Öseink nyomán Belső-Ázsiában IV.] Budapest: L'Harmattan Kiadó. 
Boross Balázs 2004. „Antropológiai módszerek, terepmunka és a 'bevezető fejezetek'.” Kisebbségkutatás 2004/3: 381-387. (Online elérhetőség: http://epa.oszk.hu/00400/ 00462/00023/pdf/terep02.pdf, utolsó megtekintés: 2017. szeptember 11.)

Cséfalvay Zoltán 2004. Globalizáció 1.0. Budapest: Nemzeti Tankönyvkiadó.

Gilberg, Rolf - Svantesson, Jan Olof 1996. „The Mongols, Their Land and History.” In: O. Bruun - O. Odgaard (eds.) Mongolia in Transition: New Patterns, New Challenges. Richmond: Curzon Press, 5-22.

Humphrey, Caroline - Sneath, David 1995. „Pastoralism and institutional change in Inner Asia: comparative perspectives from the MECCIA research project." Pastoral Development. Network 39: 1-22. (https://www.odi.org/sites/odi.org.uk/files/odi-assets/ publications-opinion-files/5425.pdf, utolsó megtekintés: 2016. október 11.)

Lxagwa, C. 1997. Xotgoidiin Düüregč wangiin xošuunii tüüx. Ulaanbaatar.

Robinson, Bernadette 1995. „Mongolia in Transition: a role for distance learning?” Open Learning 10/3: 3-15. (Online elérhetőség: http://www.eldis.org/fulltext/disted.pdf utolsó megtekintés: 2017. december 6.)

Róna-Tas András 1961. Nomádok nyomában. Budapest: Gondolat Kiadó.

Shi, Anqing 2012. Rural Out-Migration and Family Life in Cities in Mongolia. (Background Paper,East Asian and Pacific Region/CMU The World Bank [May 12, 2011], http://documents.worldbank.org/curated/en/432631468323707757/pdf/651590 WP0P12230on0v20final00PUBLIC0.pdf, utolsó megtekintés: 2018. január. 22.)

Sneath, David 2006. „The Rural and the Urban in Pastoral Mongolia.” In: Ole Bruun Li Narangoa (eds.) Mongols from Country to City. Floating Boundaries, Pastoralism and City Life in the Mongol Lands. Copenhagen: Nordic Institute of Asian Studies Press, 140-161.

Szilágyi, Zsolt 2010a. „Is the Post-Communist Transition Over? Economic and Social Factors Influenting the Mongolian Democratozation Process." In: Krisztián CsaplárDegovics - Miklós Mitrovits - Csaba Zahorán (eds.) After Twenty Years... Reasons and Consequences of the Transformation in Central and Eastern Europe. Berlin: OEZ Berlin Verlag, 109-133.

Szilágyi, Zsolt 2010b. „Városlakó nomádok. A politikai változás és a globalizáció hatásai a mongol társadalomban.” In: Berta Péter (szerk.) Ethno-Lore XXVII. Budapest: MTA Néprajzi Kutatóintézet, 325-337.

Szilágyi, Zsolt 2015. Keleten van-e Mongólia? A mongol demokrácia elmúlt 25 éven. [Mühelytanulmányok 9. PPKE Modern Kelet-Ázsia Kutatócsoport] Budapest. (https: // btk.ppke.hu/uploads/articles/447809/file/mkkcsmuhely09_mongolia_demokracia.pdf, utolsó megtekintés: 2017. december 11.)

Szilágyi, Zsolt 2016. „Lingering Nomad Ideology in 21th Century Mongolia.” Acta Ethnographica Hungarica 61/1: 197-212.

Szmyt, Zbigniew 2012. „The History of Nation and Ethnicity in Mongolia.” Sensus Historiae VIII (2012/3): 11-28. http://www.sensus-historiae.amu.edu.pl/index.php/ sensus/article/view/12/10 (utolsó megtekintés 2018. január 10.) 


\section{Internetes források}

https://www.adb.org/sites/default/files/linked-documents/39256-023-mon-ssa.pdf

(utolsó megtekintés: 2017. december 11.)

http://www.fukuoka.unhabitat.org/kcap/activities/egm/2013/pdf/egm15_en.pdf

(utolsó megtekintés: 2018. január 5.)

http://www.mestersegekunnepe.hu/ (utolsó megtekintés: 2018. január 21.)

http://www.nso.mn/index.php (utolsó megtekintés: 2017. december 12.)

http://www.slideshare.net/Ochiro/mongolia-2010-population-census-main-findings

(utolsó megtekintés: 2017. december 14.)

http://www.un.org/esa/population/publications/wpp2006/WPP2006_Highlights_rev.pdf

(utolsó megtekintés: 2018. január 5.)

http://whc.unesco.org/en/statesparties/mn (utolsó megtekintés: 2018. január 21.) 